\title{
KHUL'MENURUT IMAM SYAFI'I DAN IMAM HANBALI: MENCARI RELEVANSINYA DI INDONESIA
}

\author{
Edi Kurniawan \\ Fakultas Syariah UIN \\ Sulthan Thaha Saifuddin \\ Jambi \\ edikurniawan@uinjambi. \\ ac.id

\section{Ulul Albab Fadhlan} \\ Fakultas Syariah UIN \\ Sulthan Thaha Saifuddin \\ Jambi \\ UAFadhlan@gmail.com
}

\section{Illy Yanti}

Fakultas Syariah UIN

Sulthan Thaha Saifuddin

Jambi

illy.yanti@yahoo.com

\begin{abstract}
Khul' or divorce requested by a wife is one of the causes marital termination. According to Imam Syafi'i, khul' is a divorce (talak) with an 'iddah of three menstruat cycles. In contrast, for Imam Hanbali, khul' is fasakh in which its 'iddah is one menstrual cycle and its legality does not require a judge's decision. This difference has dissimilar legal implications when it is applied in Indonesia. Therefore, this article aims to seek the both relevancies in the context of Indonesian law, especially under the Compilation of Islamic Law and the nature of the religious practice of Indonesian Muslims. After examining the relevant literature sources, this article shows that, both Imam Syafi'i and Imam Hanbali agree that khul' is like a buy-sell contract, and hence a judge's decision is not required. However these both agremeents are not relevance under the Compilation of Islamic Laws, but the Imam Hanbali's fiqh in which khul' as fasakh would be difficult to seek its relevance. Thus, the fiqh of Imam Syafi'i is more appropriate, since beside it is used as a basis for the Compilation of Islamic Laws the majority of Indonesian Muslims embrace the Syafi'i mazhab.
\end{abstract}

Keywords: Khul', Imam Syafi'i, Imam Hanbali, Relevance, Indonesia

\begin{abstract}
Abstrak: Khul' atau tebus talak merupakan salah satu penyebab putusnya perkawinan. Menurut Imam Syafi'i, khul' adalah talak dengan 'iddah tiga kali haid. Sebaliknya, menurut Imam Hanbali, kedudukan khul' adalah fasakh dengan 'iddah satu kali haid serta ketetapannya tidak memerlukan keputusan hakim. Perbedaan ini memiliki implikasi hukum yang berbeda-beda jika diterapkan di Indonesia. Karena itu, tulisan ini mencoba mencari relevansi keduanya dalam konteks hukum di Indonesia khususnya di
\end{abstract}


bawah Kompilasi Hukum Islam dan watak pengamalan beragama umat Islam Indonesia. Setelah menelaah sumber-sumber pustaka yang relevan, tulisan ini menunjukkan bahwa, baik Imam Syafi'i maupun Imam Hanbali bersepakat bahwa khul' layaknya seperti (akad) jual beli sehingga tidak membutuhkan hakim di pengadilan. Walaupun kedua kesepakatan ini tidak relevan ditinjau dari sisi kompilasi hukum Islam, fiqih Imam Hanbali yang menyatakan khul' sebagai fasakh sulit untuk menemukan keselarasannya. Karena itu, pendapat Imam Syafi'i lebih tepat, selain ia dijadikan sebagai dasar penyusunan Kompilasi Hukum Islam, juga karena umat Islam Indonesia mayoritas bermazhab Syafi'i.

Kata Kunci: Khul', Imam Syafi'i, Imam Hanbali, Relevansi, Indonesia

\section{Pendahuluan}

Perkawinan ialah ikatan lahir batin antara seorang pria dengan seorang wanita sebagai suami istri dengan tujuan membentuk keluarga (rumah tangga) yang bahagia dan kekal berdasarkan Ketuhanan Yang Maha Esa1 dengan tujuan untuk mewujudkan kehidupan rumah tangga yang sakinah, mawaddah, dan rahmah.2 Namun di tengah jalan, berbagai kendala dihadapi oleh pasangan suami istri, sehingga berujung pada perceraian. Meskipun tidak ada orang yang menginginkannya, namun dalam kondisi tertentu, perceraian terkadang menjadi solusi terbaik walaupun amat dibenci oleh Allah.3

Secara umum, ada dua bentuk perceraian di dalam Islam. Pertama, cerai atas permintaan suami atau disebut dengan talak. Kedua, cerai atas permintaan istri, bisa disebut fasakh (pembatalan perkawinan) atau pun khul' (cerai gugat/tebus

\footnotetext{
1 Pasal 1 Undang-Undang Nomor 1 Tahun 1974 tentang Perkawinan 2 Kompilasi Hukum Islam, Pasal 3

3 Al-Ḥâfiz ibn Ḥajar al-'Asqalānī, Bulūgh al-Marām (Jakarta: Ummul Qura, 2015), 796.
} 
talak). Para ulama fiqih bersepakat bahwa khul' dibenarkan di dalam Islam apabila ada sebab yang menghendaki seperti suami cacat jasmani atau rohani, jelek kelakuannya atau tidak melaksanakan kewajibannya sebagai suami dan isteri takut kalau melanggar hukum disebabkan tidak taat kepada suaminya.4 Namun, mereka berbeda pendapat, adakah perceraian atas permintaan istri disebut $\mathrm{khul}^{\prime}$ atau fasakh. Beberapa berpendapat $\mathrm{khul}^{\prime}, 5$ sebagian berpendapat fasakh.6 Dua pendapat ini diwakili oleh dua tokoh besar perintis mazhab fiqh, Imam Syafi'i dan Imam Hanbali. Bagi Imam Syafi'i, khul' adalah talak.7 Sementara menurut Imam Hanbali dalam beberapa riwayat mengatakan bahwa khul' adalah fasakh, bukan talak. 8 Perbedaan ini, jika diterapkan di Indonesia, akan menimbulkan konsekuensi hukum yang berbeda. Hanya saja, pesoalan ini belum mendapat perhatian yang berarti dari beberapa peneliti. Kajian-kajian yang ada hanya berkaitan

4 Selengkapnya lihat, Ibn Qayyim al-Jawziyyah, Zād Al-Ma'ād, Vol. 5 (Beirut: Dār al-Kutub al-'Ilmiyyah, 1998), 6; Sayyid Sābiq, Fiqh Al-Sunnah, Vol. 4 (Kuala Lumpur: Al-Hidayah Publication, 2009), 433; 'Abd al-Raḥmān alJāzirī, Al Fiqh 'Alā Madhāhib Al-Arba'ah, Vol. 4 (Beirut: Dār al-Kutub al 'Ilmiyyah, 1971), 164; Musțafā Sa'īd al-Khin, Al-Fiqh Al-Manhajī 'Alā Madhhab Al-Shāfi'î, Vol. 4 (Beirut: Dār al-Qalam, 1992), 111; 'Abd alRaḥmān al-Jāzirī, Al Fiqh 'Alā Madhāhib Al-Arba'ah, Vol. 4 (Beirut: Dār alKutub al-'Ilmiyyah, 1971), 164; Sulayman ibn 'Umar, Hāshiyyat Al-Jamal 'Alā Sharh Al-Manhāj, Vol. 7 (Beirut: Dār al-Kutub al-'Ilmiyyah, 1971), 327; Wahbah al-Zuhaylī, Al-Fiqh Al-Islāmī Wa Adillatuhu, Vol. 7 (Damascus: Dār al-Fikr, 1984), 527.

5 Talak adalah perceraian yang hanya dijatuhkan oleh suami kepada istri dengan lafadz yang jelas. Dibatasi hingga dua kali sehingga masih dapat rujuk. Apabila sudah tiga kali maka tidak dapat rujuk atau menikah lagi

6 Fasakh adalah pembatalan pernikah yang telah terjadi dalam artian pernikahan terputus melalui pengadilan yang hakikatnya hak suami dan istri namun seorang hakim juga dapat memutuskan perkawinan mereka, disebabkan oleh sesuatu yang diketahui setelah akad berlangsung, misalnya tidak terpenuhi rukun dan syarat pernikahan atau melanggar ketentuan yang mengharamkan perkawinan.

7 Lihat Abu Ahmad Najieh, Fikih Mazhab Syafi'i (Bandung: Marja, 2017), 629-630.

8 Lihat Muhammad Utsman al-Khasyt, Fikih Wanita Empat Mazhab (Jakarta : Elex Media Komputindo, 2017), 333-335. 
dengan; fenomena tinggi cerai $k_{h u l}$ di beberapa wilayah di Indonesia, 9 perlindungan hukum terhadap perempuan dalam cerai $k h u l ', 10$ pemikiran para tokoh tentang $k h u l^{\prime}, 11$ dan perbandingan konsep $\mathrm{khul}^{\prime}$ antara fiqh dan Undang-Undang Perkawinan di Indonesia.12 Mengisi kekosongan tersebut, tulisan ini akan mendiskusikan khul' menurut Imam Syafi'i dan Imam Hanbali sekaligus mencari relevansinya dalam konteks keindonesian.

Untuk mencapai tujuan di atas, tulisan ini dimulai dengan mengulas tentang pengertian $\mathrm{khul}^{\prime}$ beserta dasar-dasarnya dari al-Qur'an dan hadis. Selanjutnya, ia mengulas tentang pendapat Imam Syafi'i dan Imam Hanbali tentang khul' sekaligus merumuskan persamaan dan perbedaan keduanya besarta

9 Isnawati Rais, “Tingginya Angka Cerai Gugat (Khulu') di Indonesia: Analisis Kritis Terhadap Penyebab Dan Alternatif Solusi Mengatasinya," Al-'Adalah 12, no. 1 (2014): 191-204.

10 Syaifuddin Syaifuddin and Sri Turatmiyah, "Perlindungan Hukum Terhadap Perempuan dalam Proses Gugat Cerai (Khulu') di Pengadilan Agama Palembang," Jurnal Dinamika Hukum 12, no. 2 (2012): 248-60; A Salma, A Elfia, and Afifah Djalal, "Perlindungan Hukum Bagi Perempuan dan Anak (Analisis Putusan Hakim Tentang Nafkah Madhiyah Pada Pengadilan Agama Di Sumatera Barat)," Istinbath 16, no. 1 (2017): 106-208.

11 Ahmad Hoyir, "Pendapat Imam Mâlik Bin Anas Tentang Khulu ' dan Relevansinya Dengan Hukum Perkawinan Di Indonesia," Asy-Syari'ah 16, no. 2. Zaini Nasohah, "Pembubaran Perkahwinan Secara Khuluk dan Kesannya Ke Atas Tempoh Idah.," Islamiyyat: International Journal of Islamic Studies, no. 33 (2011).014): 159-68; Ria Noviani, "Pandangan Ibnu Qayyim Tentang Iddah Khulu'" (UIN Ar-Raniry Banda Aceh, 2017); Arif Marsal, "Infertilitas Sebagai Alasan Khulu' Perspektif Ulama," YUDISIA: Jurnal Pemikiran Hukum dan Hukum Islam 9, no. 1 (2018): 138-51; Raniah Mumtaz, Rumba Triana, and Aceng Zakaria, "Konsep Khulu' dalam Al-Qur'an: Studi Analisis Tafsir Ayat Tentang Khulu'Menurut Imam Qurtubi," ProsA IAT: Prosiding Al Hidayah Ilmu Al-Quran dan Tafsir 1, no. 1 (2020): 50-62; Nasaiy Aziz, "Penyebutan 'Iwạ̣ dalam Penjatuhan Khulu': Kontribusi Abu Isḥāq AlSyīrāzī," SAMARAH: Jurnal Hukum Keluarga dan Hukum Islam 2, no. 1 (2018): 73-94.

12 Nouvan Moulia, "Kedudukan Khuluk dalam Perspektif Undang-Undang Perkawinan Indonesia dan Fikih Islam (Analisis Putusan Pengadilan Agama Pasir Pengaraian, Nomor 273/Pdt. G/2015/PA. Ppg)," Ius Civile: Refleksi Penegakan Hukum dan Keadilan 2, no. 1 (2018). 
dalil-dalil yang mereka gunakan. Terakhir, sebelum membuat suatu kesimpulan, tulisan ini menganalisis kedua pendapat tersebut dalam upaya mencari relevansi keduanya dalam konteks keindonesian.

\section{Tinjauan Umum Tentang Khul}

Secara bahasa, khul' bermakna mencabut,13 karena masing-masing suami istri mencabut pakaian yang lain. Persamaan antara pakaian laki-laki dan perempuan bertemu dengan pasangannya mengandung makna memeluk dan tidur bersama.14 Selain itu, khul' juga berarti melepas pakaian.15 Wanita adalah pakaian bagi pria dan pria adalah pakaian bagi wanita (al-Baqarah (2): 187). Dalam hubungannya dengan $k_{h u l}$, pakaian di sini merupakan istri yang berupaya melepaskan pakaian dari suaminya.

Secara istilah, khul' dapat diartikan sebagai putusnya perkawinan dengan menggunakan uang tebusan, ganti rugi atau 'iwād. 16 Khul' diperbolehkan, sebagaimana di dalam alQur'an: Talak yang dapat dirujuk itu dua kali. Setelah itu suami dapat menahan dengan baik atau melepaskan dengan baik. Tidak halal bagi kamu mengambil kembali sesuatu yang telah kamu berikan kepada mereka, kecuali keduanya (suami dan istri) khawatir tidak mampu menjalankan hukum hukum Allah, maka keduanya tidak berdosa atas bayaran yang harus diberikan oleh istri untuk menebus dirinya. Itulah hukum-hukum Allah, maka janganlah kamu melanggarnya. Barangsiapa yang melanggar hukum-hukum Allah, mereka itulah orang-orang zalim. (Q.S al-Baqarah (2): 229).

Ayat di atas menjelaskan perceraian dengan cara $\mathrm{khul}^{\circ}$ yang dibolehkan jika istri sudah tidak sanggup lagi hidup

13https://www.almaany.com/en/dict/ar-en/\%D8\%AE\%D9\%84\%D8\%B9/ terjemahan kaidah bahasa Arab diakses pagi 16 Mei 2020 pukul 01.23 WIB 14 Abdul Aziz Muhammad Azzam dan Abdul Wahhab Sayyed Hawwas, Fiqh Munakahat (Jakarta: Amzah, 2009), 297.

15 Abu Malik Kamal, Fiqh Sunnah Lin Nisaa (Depok: Pustaka Khazanah Fawaid, 2016), 860.

16 Muhammad Syaifuddin, dkk, Hukum Perceraian (Jakarta: Sinar Grafika, 2016), 139. 
bersama suaminya dengan alasan adanya kemaslahatan bagi keduanya, jika perkawinan tersebut tetap dilanjutkan, maka akan menimbulkan kemudharatan yang besar bagi sang istri. Dengan demikian, sang istri boleh menebus diri (gugat cerai) dari suaminya dengan dengan sejumlah uang yang dalam istilah fiqih disebut dengan 'iwād.

Selain itu, syariat $\mathrm{khul}^{\prime}$ juga ditemukan di dalam hadis Nabi saw. seperti cerita tentang Rasulullah shalallahu 'alaihi wasallam keluar untuk melaksanakan shalat subuh, lalu beliau menjumpai Habibah binti Sahl di depan pintu rumahnya dalam keadaan gelap gulita. Rasulullah bertanya: "Siapa ini?". Ia menjawab: "saya Habibah binti Sahl wahai Rasulullah". Rasulullah menjawab: "Ada apa denganmu?". Ia menjawab: "tidak saya dan juga tidak Tsabit bin Qais suamiku". Ketika Tsabit datang, Rasulullah shalallahu 'alaihi wasallam bersabda kepadanya: "Sesungguhnya Habibah binti Sahl telah menyebutkan apa yang dikehendaki oleh Allah untuk disampaikan (Habibah mengatakan perihal hubungan mereka)." Habibah berkata: "Wahai Rasulullah, apa yang telah diberikan kepadanya masih ada pada saya sekarang (mahar)." Rasulullah shalallahu 'alaihi wasallam bersabda pada Tsabit: "Ambillah (mahar) tersebut." Tsabit lalu mengambil mahar tersebut dan Habibah kembali kepada keluarganya. (H.R. anNasa'i).17

Hadits di atas tidak membolehkan istri meminta khul' jika tidak ada alasan yang jelas. Hal ini sesuai dengan hadis lain bahwa Nabi saw. bersabda: "istri-istri yang meminta cerai kepada suaminya tanpa alasan adalah munafik." (H.R atTirmidzi).18 Dalam hadis yang lain juga dijelaskan bahwa: "wanita mana saja yang meminta cerai dari suaminya tanpa alasan yang dibenarkan, maka ia tidak akan mencium aroma surga." (H.R Abu Dawud).19

17 Ibn Kathīr, Tafsīr al-Qur'ān al-'Azịim, Vol. I (Beirut: Dār Ibn Ḥazm, 2000), 289.

18 Ibid., I: 289.

19 Ibid., I: 289. 
Dari hadis-hadis dan ayat-ayat di atas, para ulama menarik kesimpulan bahwa bahwa seorang istri boleh meminta khul' kepada suaminya karena alasan-alasan tertentu seperti suami terjangkit penyakit gila (al-junūn), lepra (al-baraș), kusta (al-judhām), vagina tersumbat oleh tulang yang berbentuk seperti tanduk kambing (al-qarn), zakar terputus (al-jubb), dan mati pucuk (al-innah),20 mati pucuk (al-'innah), terjadinya pernikahan antara saudara sekandung dan sepersusuan, murtad,21 dan adanya aib (al-'ayb) pada suami.22 Al-Jaziri dalam al-Fiqh 'Alā Madhāhib al-Arba'ah menerangkan makna aib dengan lebih terperinci seperti zakar terputus (al-jubb), mati pucuk (al-'innah), buah zakar terpotong (al-khișā'), lemah syahwat (al-i'tiraḍ), vagina tersumbat oleh daging (al-ratq) atau oleh tulang yang berbentuk seperti tanduk kambing (alqarn), daging menutupi vagina sehingga keringat menggenanginya (al-'alf), menyatunya saluran vagina dengan pembuangan air kecil dan air besar (al-ifda'), dan vagina yang sangat menjijikkan serta berbau (al-bakhr).23 Selain itu, para ulama juga menerima alasan-alasan $k h u l^{\prime}$ seperti suami tidak mampu memberikan nafkah,24 ghayb25 atau tidak jelas kemana rimbanya serta shiqaq26 atau pertengkaran antara suami dan istri secara terus menerus.

20 Ibn Qayyim al-Jawziyyah, Zād Al-Ma'ād, Vol. 5 (Beirut: Dār al-Kutub al'Ilmiyyah, 1998), 6.

21 Sayyid Sābiq, Fiqh Al-Sunnah, Vol. 4 (Kuala Lumpur: Al-Hidayah Publication, 2009), 433.

22 Ibid.

23 'Abd al-Raḥmān al-Jāzirī, Al Fiqh 'Alā Madhāhib Al-Arba'ah, Vol. 4 (Beirut: Dār al-Kutub al -'Ilmiyyah, 1971), 164

24 Taqī al-Dīn Abī Bakr, Kifāyat Al-Akhyār Fī Hall Ghāyat Al-Ikhtiṣār (Beirut: Dār al-Kutub al-'Ilmiyyah, 2001), 584.

25 Sulayman ibn 'Umar, Hāshiyyat Al-Jamal 'Alā Sharh Al-Manhāj, Vol. 7 (Beirut: Dār al-Kutub al-'Ilmiyyah, 1971), 327.

${ }_{26}$ Wahbah al-Zuhaylī, Al-Fiqh Al-Islāmī Wa Adillatuhu, Vol. 7 (Damascus: Dār al-Fikr, 1984), 527. 


\section{Khul' Menurut Imam Syafi'i}

Menurut Imam Syafi'i, khul' adalah talak, sehingga tidak dijatuhkan kecuali dengan ucapan talak. Apabila istri memberikan 'iwā istrinya meskipun tidak membutuhkan niat, suami akan melepaskan istrinya.27

Imam Syafi'i mengatakan, jika suami melakukan $\mathrm{khul}^{\prime}$ terhadap istrinya dan suami meniatkan talak tetapi tidak mengucapkan bilangan tertentu, maka khul' tersebut jatuh sebagai talak satu dan suami tidak memiliki hak untuk rujuk kepada istrinya, karena khul' termasuk jual beli dan suami tidak boleh memiliki harta istri.28 Imam Syafi'i berhujjah dengan firman Allah subhanahu wa ta'ala: "talak (yang dapat dirujuk) itu dua kali....." (Q.S al-Baqarah ayat 229).29

Imam Syafi'i memahami maksud ayat di atas bahwa talak tersebut jatuh karena dijatuhkan oleh suami dan khul' hanya dijatuhkan oleh suami meskipun istri yang meminta. Jika suami melakukan $\mathrm{khul}^{\prime}$ terhadap istrinya, lalu suami menyebutkan talak, maka itu adalah talak. Hal itu sesuai dengan niat suaminya, seperti menyebutkan kalimat yang sama dengan kalimat talak dengan niat talak. Dengan demikian, setiap kalimat yang digunakan untuk menjatuhkan talak tanpa khul', maka itu adalah $\mathrm{khul}^{\prime}$ dan $\mathrm{khul}^{\prime}$ tersebut jatuh dengan niat talak. Sekiranya kalimat tersebut bukan bermaksud talak, maka 'iwā harus dikembalikan kepada istri.30 Jika suami meniatkan $\mathrm{khul}^{\prime}$ dua atau tiga, maka $\mathrm{khul}^{\prime}$ dijatuhkan seperti yang diniatkan oleh suami dan jika suami mengucapkan kalimat khul' kepada istrinya dengan bilangan talak, maka itu adalah talak. Dalam kitabnya, Imam Syafi'i memberikan penjelasan dari riwayat Utsman ra. bahwa Ummu Bakrah melakukan khul' terhadap suaminya yang bernama Abdullah bin Usaid, kemudian keduanya mendatangi Utsman untuk urusan itu. Utsman

27 Imam Syafi'i Abu Abdullah Muhammad bin Idris, al-Umm, Vol. 10 (Jakarta: Pustaka Azzam, 2014), 372.

28 Ibid., 376.

29 Ibid., 377.

30 Ibid. 
berkata: "Itu sama dengan satu kali talak, kecuali kamu menyebutkan suatu bilangan sehingga khul' itu dijatuhkan sesuai bilangan yang kamu sebutkan.31

Pendapat yang benar dalam masalah ini adalah seperti yang diriwayatkan dari Utsman ra., meskipun suami tidak menyebut $k h u l$ ' sebagai satu talak karena bersumber dari pihak suami, maka itu adalah talak. Apabila suami mengucapkan lebih dari satu talak maka itu sesuai yang diucapkan oleh suami kepada istrinya. 32

Imam Syafi'i juga menjelaskan, bahwa 'iddah wanita yang telah dijatuhkan $\mathrm{khul}^{\prime}$ oleh suami, tidak berbeda dengan 'iddah wanita yang telah dijatuhkan talak. Istri berhak terhadap tempat tinggal, tetapi tidak berhak untuk mendapatkan nafkah kecuali istri sedang hamil.33 Mengenai berapa lama waktu bagi suami setelah bercerai untuk memberikan nafkah ketika istri sedang hamil, penulis mencoba menyesuaikan dalil yang sebelumnya, suami akan memberikan nafkah 'iddah hingga melahirkan.

Adapun alasan Imam Syafi'i, Ia mengatakan bahwa istri tidak berhak mendapatkan nafkah karena suaminya tidak berhak rujuk kembali kepada istrinya. Jika suami telah melakukan khul' terhadap istrinya, kemudian melakukan talak di masa 'iddah, maka tidak ada talak karena talak itu tidak berarti terhadap istrinya, karena suami tidak memiliki hak rujuk.34

Imam Syafi'i mengatakan, bahwa terdapat riwayat mengenai hal ini dari Ibnu Abbas ra., bahwa wanita yang melakukan $\mathrm{khul}^{\prime}$ lalu dijatuhkan talak oleh suaminya, maka talak itu tidak jatuh kepada istrinya karena suami melakukan talak kepada orang yang bukan istrinya lagi.35 Dari sini penulis mencoba untuk menyimpulkan, bahwa yang terjadi disini yaitu khul' adalah talak bä'in. Khulyang dijatuhkan oleh suami

\footnotetext{
31 Ibid., 378.

32 Ibid.

33 Ibid.

34 Ibid., 379.

35 Ibid.
} 
dengan menyebutkan bilangan talak maka 'iddah yang diterima istri tiga kali qurü' sehingga apabila ingin kembali kepada suaminya, maka istri harus menikah dengan pria lain kemudian bercerai. Adapun yang menjadi landasan hukum bagi penulis, bahwa 'iddah wanita yang dijatuhkan oleh suami adalah tiga kali qurū' disebabkan kedudukan khulu' menurut Imam Syafi'i adalah talak. Sebagaimana firman Allah subhanahu wa ta'ala:"Dan para istri yang diceraikan (wajib) menahan diri mereka (menunggu) tiga kali qurü'." 36

\section{Khul' Menurut Imam Hanbali}

Seorang wanita yang tidak mencintai suaminya karena wajah, akhlaq, agama, umur suami yang tua, lemah badannya, tidak mau melarang suaminya berhubungan badan dan lainnya karena khawatir berbuat maksiat dikarenakan pelarangannya tersebut, maka dibolehkan bagi si wanita untuk menebus dirinya dengan mengembalikan mahar yang telah diberikan suami atau memberikan 'iwā d sebagai ganti rugi kepada suaminya. 37

Ibnu Qudamah dalam kitabnya mengatakan, Imam Hanbali berpendapat bahwa diperbolehkan melakukan $\mathrm{khul}^{\prime}$ tanpa campur tangan pemerintah atau hakim yang mampu memberikan keadilan. $38 \mathrm{Hal}$ ini disebabkan kedudukan $\mathrm{khul}^{\circ}$ adalah fasakh dan $k h u l$ ' itu seperti jual beli yang saling ridha seperti iqalah (pembatalan jual beli). Pendapat Imam Hanbali juga dianut dan disepakati oleh Imam Syafi'i dan Imam Malik. 39 Dalam hal ini tidak ada perbedaan, meskipun kedudukan $\mathrm{khul}^{\circ}$ berbeda dari setiap ulama. Namun penulis mencoba menganalisa, bahwa diperlukan dua saksi berdasarkan firman Allah Swt dalam surat al-Talak ayat dua: lepaskanlah mereka dengan baik dan persaksikanlan dengan dua orang saksi yang

\footnotetext{
36 Q.S al-Baqarah ayat 229.

37 Ibn Qudāmah, al-Mughnī, Vol. 10 (Jakarta: Pustaka Azzam, 2013), 120.

38 Ibn Qudamah adalah seorang Ulama yang bermazhab Hanbali atau seorang Ulama Hanabilah

39 Ibn Qudāmah, al-Mughnī., 10: 124.
} 
adil di antara kamu dan hendaklah kamu tegakkan kesaksian itu karena Allah.

Mengenai kedudukan Khul', menurut Imam Hanbali adalah fasakh. Imam Hanbali mengatakan bahwa tidak ada hadits yang lebih shahih dalam pembahasan ini dari hadist Ibn Abbas, bahwa khul' adalah fasakh dan Ibnu Abbas telah berhujjah dengan firman Allah Swt: "Talak (yang dapat dirujuki) itu dua kali......".40 "Maka tidak ada dosa atas keduanya tentang bayaran yang diberikan oleh istri untuk menebus dirinya.41 "Kemudian jika si suami menceraikannya (setelah talak yang kedua), maka perempuan itu tidak halal lagi baginya sebelum dia menikah dengan suami yang lain .......".42

Dengan melihat ayat-ayat ini, Allah Swt menyebutkan dua kali talak, khul', kemudian talak ba'in. Seandainya $\mathrm{khul}^{\prime}$ termasuk talak maka talak akan berjumlah empat kali. Selain itu karena khul' juga adalah perpisahan yang terbebas dari ucapan talak dan niatnya, maka dari itu khul' adalah fasakh.43 Dalam hal ini penulis mengambil kesimpulan, bahwa wanita itu tidak haram bagi suami untuk dinikahi kembali oleh suami secara langsung, meskipun suami telah menjatuhkan $\mathrm{khul}^{\prime}$ kepada istrinya beberapa kali karena khul' adalah fasakh berdasarkan pendapat Imam Hanbali yang dinyatakan oleh ibnu Qudamah.

Adapun Imam Hanbali mengatakan, bahwa tidak ada riwayat yang lebih shahih dari ibnu Abbas ra. Dalam hal ini, riwayat yang dimaksud oleh Imam Hanbali adalah Nabi Saw memerintahkan Tsabit bin Qais untuk menerima kembali kebun yang telah diberikan kepada istrinya dan ceraikanlah istrimu.44

\footnotetext{
40 Q.S al-Baqarah ayat 229.

41 Q.S al-Baqarah ayat 229.

42 Ibid., 137. lihat Q.S al-Baqarah ayat 230.

43 Ibid., 138.

44 Lihat Ibn Ḥajar al-'Asqalānī dalam Bulūgh al-Maram mengenai kebolehan istri meminta khul' kepada suami, Bab Khul', 796-797.
} 
Ibnu Taimiyyah 45 dalam kitabnya mengatakan, bahwa khul' dengan tebusan adalah merupakan fasakh, dengan kata apapun terjadinya, walaupun dikatakan dengan jelas menggunakan kata talak karena termasuk di antara talak yang tiga.46 Tidak ada perbedaan meskipun dijatuhkan dengan kata talak, khul' tetap fasakh. Ini adalah riwayat Imam Hanbali yang berdasarkan riwayat dari sahabat, Abdullah ibn Abbas.47

Imam Hanbali juga menjelaskan, bahwa 'iddah wanita yang telah dijatuhkan khul' oleh suami adalah satu kali haid. Dalam hal ini penulis mendapati riwayat yang menguatkan pendapat Imam Hanbali, yaitu riwayat dari Rubayyi' binti Mu'awwidz yang berkata:"saya meminta khul' kepada suami saya lalu mendatangi Utsman ra dan bertanya tentang 'iddah saya". Utsman ra berkata, kamu tidak wajib 'iddah karena kamu hanya tinggal sebentar dengannya. Tunggulah selama satu kali haid." 48

\section{Perbandingan Pendapat Imam Syafi'i dan Hanbali Tentang Khul'}

Seperti yang telah dijelaskan di atas, bahwa menurut Imam Syafi'i, khul' adalah talak karena khul' dijatuhkan dengan ucapan dari suami seperti talak. Suami tidak dapat rujuk kembali dengan istrinya karena khul' merupakan salah satu bentuk dari jual beli.49 Suami tidak boleh memiliki harta istri setelah $\mathrm{khul}^{\prime}$ dijatuhkan,50 istrinya telah membayar `iwad untuk menebus dirinya.51 Sementara menurut Imam Hanbali, khul' adalah fasakh, karena talak hanya dapat dilakukan tiga kali.

\footnotetext{
45 Ibn Taimiyyah adalah seorang Ulama yang bermazhab Hanbali atau seorang Ulama Hanabilah

46 Lihat Surat al-Baqarah ayat 229 dan 230.

47 Lihat Faishal Alu Mubarak, Penjelasan Bulughul Maram Ibnu Hajar alAsqalani (Jakarta : Ummul Qura, 2015), 798.

48 Lihat Imam an-Nasa'i mengenai iddah wanita yang telah dijatuhkan khulu' oleh suami

49 Imam Syafi'i Abu Abdullah Muhammad bin Idris, al-Umm., 376.

50 Ibid.

51 Lihat surat al-Baqarah ayat 229.
} 
Tabel berikut menerangkan perbedaan khul' menurut Imam Syafi'i dan Hanbali:

\begin{tabular}{|c|c|c|}
\hline & & \\
\hline & 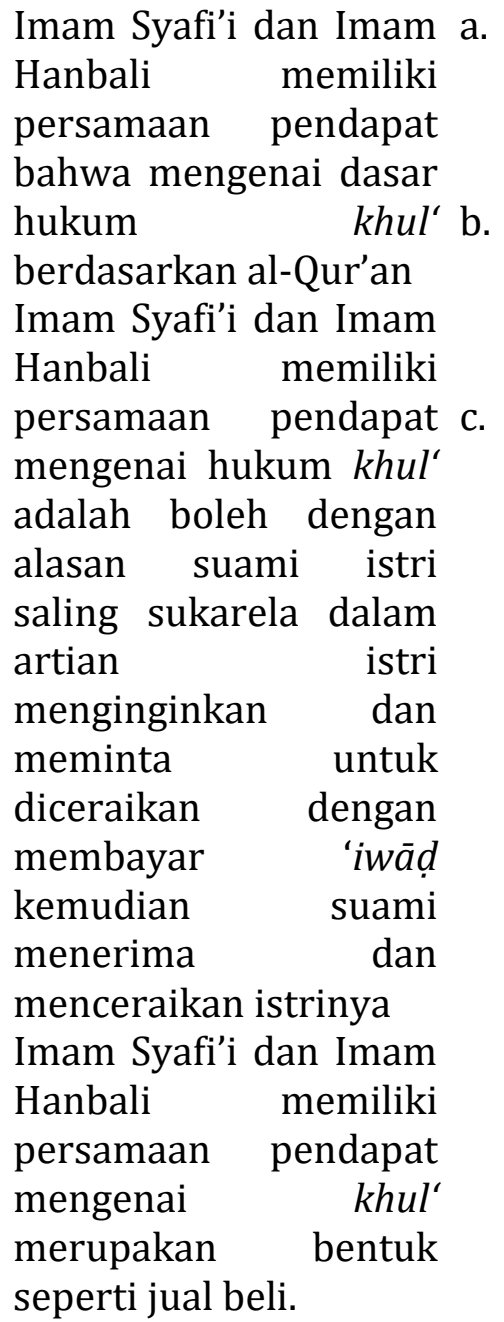 & $\begin{array}{l}\text { Imam Syafi'i dan Imam } \\
\text { Hanbali memiliki perbedaan } \\
\text { pendapat mengenai khul' } \\
\text { termasuk talak atau fasakh } \\
\text { Imam Syafi'i dan Imam } \\
\text { Hanbali memiliki } \\
\text { perberbedaan landasan } \\
\text { hukum mengenai khul' } \\
\text { Imam Syafi'i dan Imam } \\
\text { Hanbali berbeda pendapat } \\
\text { dalam menentukan 'iddah } \\
\text { dikarenakan terdapat } \\
\text { perbedaan mengenai } \\
\text { kedudukan khul' yang } \\
\text { apabila khul' adalah talak } \\
\text { maka istri menerima dan } \\
\text { menjalankan 'iddah seperti } \\
\text { 'iddah talak. Namun apabila } \\
\text { khul' adalah fasakh maka } \\
\text { 'iddah yang diterima istri } \\
\text { adalah satu kali qurü' atau } \\
\text { satu kali haid disebabkan } \\
\text { karena fasakh adalah } \\
\text { pembatalan akad yang } \\
\text { disertai 'iwad dari istri } \\
\text { untuk menebus dirinya. }\end{array}$ \\
\hline
\end{tabular}

Tabel di atas memperlihatkan, bahwa perbedaan dan persamaan pendapat dapat terjadi antara Imam Syafi'i dan Imam Hanbali karena hukum dapat berubah sesuai tempat dan waktu. Melihat dari latar belakang Imam Syafi'i dan Imam Hanbali, maka tidak diragukan, bahwa Imam Hanbali adalah 
murid Imam Syafi'i ketika berada di Irak sebelum berada di Mesir.

Adapun tempat dan waktu yang menjadi penyebab perbedaan dan persamaan antara Imam Syafi'i dan Imam Hanbali adalah berdasarkan kaidah dari ibnu Qayyim alJauziyyah52 yaitu: "Perubahan Fatwa karena perubahan zaman, tempat, keadaan, niat dan kebiasaan." 53

\section{Relevansi Pendapat Imam Syafi'i dan Hambali dalam Konteks Keindonesiaan}

Indonesia adalah negara hukum yang demokratis. Karena itu, kekuasaan harus berlandasankan pada Pancasila sehingga setiap aspek dan kaidah kehidupan, keagamaan, kemasyarakatan, kenegaraan dan pemerintahan senantiasa berdasarkan landasan hukum. Di lain pihak, mayoritas penduduk Indonesia adalah beragama Islam, sementara Islam itu sendiri bersifat universal dan komprehensif (sempurna) sehingga setiap aspek akidah, ibadah dan muamalah (ekonomi, sosial, politik dan hukum) dapat diterima dan dilaksanakan oleh manusia. Bagian ini bermaksud untuk, bagaimana menempatkan antara agama dan masyarakat Indonesia, khususnya dalam kasus khul'.

Di Indonesia, khul' diatur dalam Kompilasi Hukum Islam. Sebelum diberlakukannya acara khul', Pengadilan Agama hanya mengenal dua jenis perkara perceraian, yaitu perkara permohonan cerai talak oleh suami dan perkara cerai gugat dari istri. 54

Adapun mengenai pendapat Imam Hanbali tentang khul', penulis tidak dapat terlepas dari ulama Hanabilah sehingga terdapat beberapa pendapat dari Imam Hanbali diwakilkan oleh mereka. Diketahui bahwa Imam Hanbali adalah ulama

52 Ibnu Qayyim al-Jauziyyah adalah seorang Ulama yang bermazhab Ahmad atau Ulama Hanabilah

53 Ibn Qayyīm Al-Jawziyyah, I'lām Al-Muwāqqi'īn, Vol. 3 (Bairūt: Dār al-Fikr, n.d.).

54 Aris Bintania, Hukum Acara Peradilan Agama Dalam Kerangka Fiqh alQadha (Depok: Raja Grafindo Persada, 2012), 141. 
dalam bidang hadits dan fiqih. Selama masa hidupnya, Imam Hanbali tidak menuliskan kitab mengenai hukum Islam seperti gurunya.

Adapun menurut Imam Syafi'i, penulis menguraikan sebagai berikut:

\begin{tabular}{|c|c|c|}
\hline No & Imam Syafi'i & Kompilasi Hukum Islam \\
\hline 1 & $\begin{array}{l}\text { Khul' adalah talak } 55 \text { dan } \\
\text { suami tidak memiliki } \\
\text { hak untuk rujuk kepada } \\
\text { istri.56 }\end{array}$ & $\begin{array}{l}\text { Pasal 161: } \text { Perceraian } \\
\text { dengan jalan khul' } \\
\text { mengurangi jumlah talak } \\
\text { dan tidak dapat dirujuk. }\end{array}$ \\
\hline 2 & $\begin{array}{l}\text { 'Iddah wanita yang telah } \\
\text { dijatuhkan khul' oleh } \\
\text { suami maka menerima } \\
\text { dan menjalankan 'iddah } \\
\text { seperti 'iddah dalam } \\
\text { talak .57 }\end{array}$ & $\begin{array}{l}\text { Pasal 155: 'iddah wanita } \\
\text { (janda) yang putus } \\
\text { perkawinannya karena } \\
\text { khuluk, fasakh, dan li'an } \\
\text { berlaku 'iddah sebagaimana } \\
\text { 'iddah dalam talak. }\end{array}$ \\
\hline 3 & 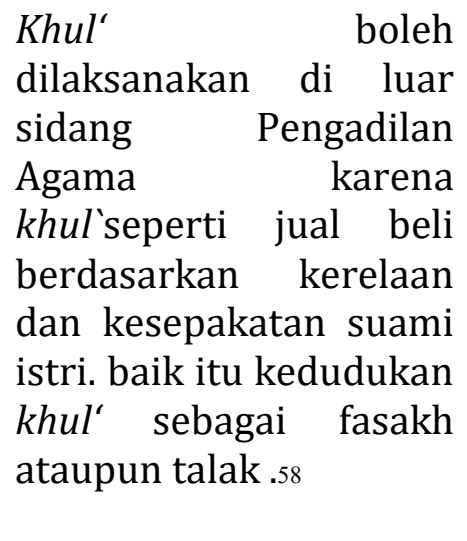 & $\begin{array}{l}\text { Pasal 115: Perceraian hanya } \\
\text { dapat dilakukan di depan } \\
\text { sidang Pengadilan Agama } \\
\text { setelah Pengadilan Agama } \\
\text { tidak berhasil } \\
\text { mendamaikan kedua belah } \\
\text { pihak. } \\
\text { Pasal 123: Perceraian itu } \\
\text { terjadi terhitung pada saat } \\
\text { perceraian itu dinyatakan di } \\
\text { depan sidang. }\end{array}$ \\
\hline
\end{tabular}

Dari pemaparan di atas dapat dipahami, bahwa $\mathrm{khul}^{\circ}$ menurut pendapat Imam Syafi'i mempunyai relevansi dengan

\footnotetext{
55 Imam Syafi'i Abu Abdullah Muhammad bin Idris, al-Umm., 376

56 Ibid., 380.

57 Ibid., 378.

58 Ibn Qudāmah, al-Mughnī., 376.
} 
Kompilasi Hukum Islam. Pasal 161 menjelaskan, bahwa perceraian dengan jalan $\mathrm{khul}^{\prime}$ mengurangi jumlah talak dan tidak dapat dirujuk. Pasal 155 menjelaskan, bahwa 'iddah wanita yang dijatuhkan khul' oleh suaminya, tidak berbeda dengan wanita yang telah dijatuhkan talak (diceraikan) oleh suaminya. Pasal 115 dan 123 mengatakan bahwa perceraian atau putusnya pernikahan, harus dilakukan di depan sidang Pengadilan Agama, maka yang dimaksud adalah di depan hakim. Kemudian perceraian itu terhitung sah apabila dinyatakan di depan hakim.

Berbeda dengan pendapat dari Imam Hanbali, penulis merinci sebagai berikut:

\begin{tabular}{|c|c|c|}
\hline No & Imam Hanbali & Kompilasi Hukum Islam \\
\hline 1 & $\begin{array}{l}\text { Khul' adalah fasakh } 59 \text { suami } \\
\text { hanya dapat tiga kali } \\
\text { melakukan talak } 60 \text { kepada } \\
\text { istrinya.61 Apabila khul' } \\
\text { termasuk talak maka talak } \\
\text { suami akan berjumlah } \\
\text { empat kali dan dapat } \\
\text { dirujuk meski suami telah } \\
\text { beberapa kali menjatuhkan } \\
\text { khul' kepada istrinya. }\end{array}$ & $\begin{array}{l}\text { Pasal 161: Perceraian } \\
\text { dengan jalan khul' } \\
\text { mengurangi jumlah talak } \\
\text { dan tidak dapat dirujuk. }\end{array}$ \\
\hline 2 & $\begin{array}{l}\text { 'Iddah wanita yang telah } \\
\text { dijatuhkan khul' oleh } \\
\text { suaminya adalah satu kali } \\
\text { qurü' atau satu kali suci } \\
\text { dari haid } \quad \text { karena } \\
\text { kedudukan khul' } \\
\text { fasakh.62 }\end{array}$ & $\begin{array}{l}\text { Pasal 155: 'iddah wanita } \\
\text { (janda) yang putus } \\
\text { perkawinannya karena } \\
\text { khul', fasakh, dan li'an } \\
\text { berlaku iddah } \\
\text { sebagaimana } \\
\text { dalam talak. }\end{array}$ \\
\hline
\end{tabular}

59 Ibid., 137.

60 Ibid., 138.

61 Lihat surat al-Baqarah ayat 229.

62 Lihat hadits Abu Abdurrahman Ahmad, Imam an-Nasa'i mengenai iddah wanita yang telah dijatuhkan khulu' oleh suami, Lihat juga Muhammad Utsman al-Khasyt, Fikih Wanita Empat Madzhab 
3 Khul tetap sah meski tidak dijatuhkan di hadapan hakim, karena khul' adalah fasakh (penghapusan akad) dan seperti jual beli sehingga membutuhkan pemerintah atau hakim.63
Pasal 115: Perceraian hanya dapat dilakukan di depan sidang Pengadilan Agama setelah Pengadilan Agama tidak berhasil mendamaikan kedua belah pihak.

Pasal 123: Perceraian itu terjadi terhitung pada saat perceraian itu dinyatakan di depan sidang.

Dari pemaparan di atas dapat dipahami, bahwa khul menurut Imam Hanbali adalah fasakh disebabkan suami hanya dapat tiga kali melakukan talak yang apabila khul' termasuk dalam kedudukan talak maka akan bertambah jumlahnya menjadi empat dan suami dapat melakukan rujuk kepada istrinya sedangkan dalam Kompilasi Hukum Islam pasal 161 menjelaskan bahwa perceraian dengan jalan khul' mengurangi jumlah talak dan tidak dapat dirujuk. Pada pasal 155 menjelaskan bahwa tidak terdapat perbedaan 'iddah wanita

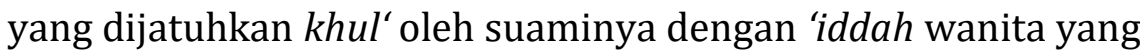
dijatuhkan talak oleh suaminya. Namun Imam Hanbali mengatakan bahwa 'iddah wanita yang dijatuhkan khul' oleh suaminya adalah satu kali qurū'.

Pada pasal 123 menjelaskan perceraian hanya dilakukan di hadapan sidang sedangkan Imam Hanbali berpendapat bahwa khul' adalah pembatalan akad seperti bentuk dari jual beli, sehingga tidak membutuhkan hakim.

Mengenai pelaksanaan perceraian dalam Kompilasi Hukum Islam pada pasal 115 dan pasal 123 bahwa perceraian hanya dinyatakan sah di depan sidang Pengadilan Agama

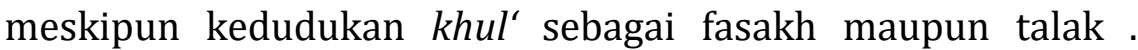
Dalam hal ini penulis juga mendapati aturan pelaksanaannya

${ }_{63}$ Ibn Qudāmah, al-Mughnī., 376. 
dalam hukum positif di Indonesia: perceraian hanya dapat dilakukan di depan sidang Pengadilan setelah Pengadilan yang bersangkutan berusaha dan tidak berhasil mendamaikan kedua belah pihak.64

Dari uraian yang diutarakan oleh penulis, Imam Syafi'i dan Imam Hanbali menimbulkan konsekuensi yang berbeda, terdapat argumen atau pendapat manakah yang lebih cocok dalam konteks hukum di Indonesia. Berdasarkan uraian di atas maka penulis berkesimpulan apabila $\mathrm{khul}^{\prime}$ dalam kaidah fiqih Imam Hanbali diterapkan dan dikorelasikan bagi umat Islam di Indonesia maka tidak akan menemukan keselarasan. Hal itu juga disebabkan pendapat Imam Syafi'i sering dijadikan dasar hukum untuk penyusunan Kompilasi Hukum Islam dan juga Indonesia adalah negara dengan umat Islam terbanyak di dunia yang mayoritas bermazhab Imam Syafi'i atau Syafi'iyah sehingga relevansi yang paling tepat ialah pendapat atau argumen dari Imam Syafi'i sebagaimana dari uraian yang tertera di atas.

\section{Penutup}

Dari penjelasan di atas dapat disimpulkan bahwa, pertama, menurut Imam Syafi'i, khul' adalah talak, karena menurutnya $\mathrm{khul}^{\prime}$ tersebut hanya dapat dijatuhkan kepada istri yang telah membayar 'iwād (uang tebusan) sehingga suami tidak memiliki hak untuk rujuk kembali. Sementara bagi istri yang dikhul', wajib menjalankan 'iddah selama tiga kali haid.

Kedua, Imam Hanbali berpendapat bahwa khul' adalah fasakh karena suami hanya dapat tiga kali melakukan talak. Apabila khul' termasuk talak, maka talak suami akan berjumlah empat kali dan dapat dirujuk meskipun suami telah beberapa kali menjatuhkan $\mathrm{khul}^{\prime}$ kepada istrinya. Sementara bagi istri, ia tetap menjalankan 'iddah selama satu kali qurū' atau satu kali suci dari haid.

Ketiga, baik Imam Syafi'i maupun Imam Hanbali

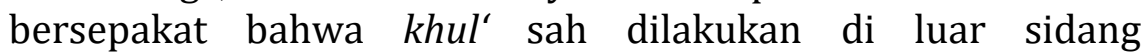

\footnotetext{
${ }_{64}$ Pasal 39 Undang-Undang Nomor 1 Tahun 1974 tentang Perkawinan
} 
Pengadilan karena akadnya seperti akad jual beli, berdasarkan kerelaan dan kesepakatan suami istri, tentu dengan dua orang saksi. Hanya saja, dalam konteks Indonesia hari ini, akan lebih baik dilakukan di Pengadilan Agama dan disahkan berdasarkan putusan hakim, sesuai aturan yang telah ditetapkan di Indonesia demi kemaslahatan mereka berdua, anak-anak, dan juga harta mereka.

Keempat, antara fiqh Imam Syafi'i dan Imam Hanbali menimbulkan konsekuensi yang berbeda. Karena itu, dalam konteks hukum di Indonesia dan watak pengamalam fiqh masyarakat Indonesia, fiqh Imam Syafi'i lebih relavan dijadikan sebagai pijakan hukum karena pendapat Imam Syafi'i sering dijadikan dasar penyusunan Kompilasi Hukum Islam dan juga Indonesia adalah negara dengan umat Islam terbanyak di dunia yang mayoritas bermazhab Imam Syafi'i.

\section{Daftar Pustaka}

Al-'Asqalānī, Al-Ḥāfiz ibn Ḥajar. Bulūgh al-Marām. Jakarta: Ummul Qura, 2015.

Al-Jawziyyah, Ibn Qayyīm. I'lām Al-Muwaqqi'īn. Bairūt: Dār alFikr, n.d.

Al-Jawziyyah, Ibn Qayyim. Zād Al-Ma'ād. Beirut: Dār al-Kutub al-'Ilmiyyah, 1998.

Al-Jāzirī, 'Abd al-Raḥmān. Al Fiqh 'Alā Madhāhib Al-Arba'ah. Beirut: Dār al-Kutub al -'Ilmiyyah, 1971.

Al-Khasyt, Muhammad Utsman. Fiqih Wanita Empat Mazhab. Jakarta: Elex Media Komputindo, 2017.

Al-Khin, Musțafā Sa'īd. Al-Fiqh Al-Manhajī 'Alā Madhhab AlShāfitì. Beirut: Dār al-Qalam, 1992.

Al-Nasā'î. Sunan al-Nasā'î. Depok: Gema Insani, 2017.

Al-Syafi'i, Muhammad bin Idris. al-Umm. Pustaka Azzam, 2014.

Al-Zuhaylī, Wahbah. Al-Fiqh Al-Islāmī Wa Adillatuhu. Damascus:

Dār al-Fikr, 1984.

Aziz, Nasaiy. "Penyebutan 'Iwaḍ dalam Penjatuhan Khul': Kontribusi Abu Isḥāq Al-Syīrāzī.” SAMARAH: Jurnal Hukum Keluarga dan Hukum Islam 2, no. 1 (2018): 7394. 
Bintania, Aris. Hukum Acara Peradilan Agama dalam Kerangka Fiqh al-Qadha. Depok: Raja Grafindo Persada, 2012.

Hawwas, Abzul Aziz Muhammad Azzam dan Abdul Wahhab Sayyed. Fiqh Munakahat. Jakarta: Amzah, 2009.

Hoyir, Ahmad. "Pendapat Imam Mâlik Bin Anas Tentang Khulu' dan Relevansinya dengan Hukum Perkawinan di Indonesia." Asy-Syari'ah 16, no. 2 (2014): 159-68.

Jawas, Yazid bin Abdul Qadir. Panduan Keluarga Sakinah. Jakarta: Pustaka Imam Syafi'i, 2011.

Kamal, Abdul Malik. Fiqh Sunnah Lin Nisaa. Depok: Pustaka Khazanah Fawaid, 2016.

Kathīr, Ibn. Tafsīr al-Qur'ān al-'Azìm. Beirut: Dār Ibn Ḥazm, 2000.

Marsal, Arif. "Infertilitas Sebagai Alasan Khul' Perspektif Ulama." YUDISIA: Jurnal Pemikiran Hukum Dan Hukum Islam 9, no. 1 (2018): 138-51.

Moulia, Nouvan. "Kedudukan Khuluk dalam Perspektif UndangUndang Perkawinan Indonesia dan Fikih Islam (Analisis Putusan Pengadilan Agama Pasir Pengaraian, Nomor 273/Pdt. G/2015/PA. Ppg)." Ius Civile: Refleksi Penegakan Hukum dan Keadilan 2, no. 1 (2018).

Mubarak, Faishal Alu. Penjelasan Bulughul Maram. Jakarta: Ummul Qura, 2015.

Mubarak, Jaih. Modifikasi Hukum Islam Studi Qawl Qadim dan Qawl Jadid. Jakarta: Raja Grafindo Persada, 2002.

Muhammad Syaifuddin, dkk. Hukum Perceraian. Jakarta: Sinar Grafika, 2016.

Mumtaz, Raniah, Rumba Triana, and Aceng Zakaria. "Konsep Khul' dalam Al-Qur'an: Studi Analisis Tafsir Ayat Tentang Khul'Menurut Imam Qurtubi." ProsA IAT: Prosiding Al Hidayah Ilmu Al-Quran Dan Tafsir 1, no. 1 (2020): 50-62.

Najieh, Abu Ahmad. Fiqih Mazhab Syafi'i. Bandung: Marja, 2017. Nasohah, Zaini. "Pembubaran Perkahwinan Secara Khuluk dan Kesannya Ke Atas Tempoh Idah." Islamiyyat: International Journal of Islamic Studies, no. 33 (2011). 
Noviani, Ria. "Pandangan Ibnu Qayyim Tentang Iddah Khul'." UIN Ar-Raniry Banda Aceh, 2017.

Qudāmah, Ibn. Al-Mughnī. Jakarta: Pustaka Azzam, 2013.

Rais, Isnawati. "Tingginya Angka derai Gugat (Khul') Di Indonesia: Analisis Kritis Terhadap Penyebab dan Alternatif Solusi Mengatasinya." Al-'Adalah 12, no. 1 (2014): 191-204.

Sābiq, Sayyid. Fiqh Al-Sunnah. Kuala Lumpur: Al-Hidayah Publication, 2009.

Salma, A, A Elfia, and Afifah Djalal. "Perlindungan Hukum Bagi Perempuan dan Anak (Analisis Putusan Hakim Tentang Nafkah Madhiyah Pada Pengadilan Agama di Sumatera Barat)." Istinbath 16, no. 1 (2017): 106-208.

Syaifuddin, Syaifuddin, and Sri Turatmiyah. "Perlindungan Hukum Terhadap Perempuan dalam Proses Gugat Cerai (Khul') di Pengadilan Agama Palembang." Jurnal Dinamika Hukum 12, no. 2 (2012): 248-60.

'Umar, Sulayman ibn. Hāshiyyat Al-Jamal 'Alā Sharh Al-Manhāj.

Beirut: Dār al-Kutub al-'Ilmiyyah, 1971.

HYPERLINK"https://www.almaany.com/en/dict/aren/\%D8\% AE\%D9\%84\%D8\%B9/"

https://www.almaany.com/en/dict/aren/\%D8\%AE\%D9\%84\%D8\%B9/ terjemahan kaidah bahasa Arab diakses pagi 16 Mei 2020 pukul 01.23 WIB 